THE MAKING OF THE

STATE ENTERPRISE SYSTEM

IN MODERN CHINA 



\section{The Making of the State Enterprise System in Modern China}

The Dynamics of

Institutional Change

Morris L. Bian

H A R VARD UNIVERSITT PRESS

Cambridge, Massachusetts, and London, England 2005 
Copyright (C) 2005 by the President and Fellows of Harvard College All rights reserved

Printed in the United States of America

Library of Congress Cataloging-in-Publication Data

Bian, Morris L., 1961-

The making of the state enterprise system in modern China : the dynamics of institutional change / Morris L. Bian

p. $\mathrm{cm}$.

Based on the author's thesis (doctoral-University of Washington) under the title: The Sino-Japanese War and the shaping of a new institutional pattern of state enterprise in China, 1935-1945. Both the scope of research and period covered have been expanded. Includes bibliographical references and index.

ISBN 0-674-01717-X (alk. paper)

1. Government business enterprises-China-History-20th century.

2. Danwei-History-20th century. 3. Industrial policy-China-History-20th century.

4. Industrial management-China-History-20th century. 5. Industrial organization-China-History-20th century. 6. Ordnance-Manufacture-History-20th century. 7. Steel industry and trade-China-History-20th century. 8. Iron industry and trade-China-History-20th century. I. Title.

HD4318.B53 2005

338.7'49'0951-dc22 
For Hui Chen 
